保健物理，34(2)，142～145（1999）

《特集：ラドンの人体への影響評価》

\title{
5. 動物実験のヒトへの外挿
}

緒 方 裕 光*1

5. Extrapolation of Animal Experimental Data to Man

Hiromitsu OGATA*1

\section{1 はじめに}

人間の健康に対する種々の環境要因のリスク評価にお いて, その数量的根拠の多くは人間集団を対象とした疫 学研究と動物を用いた実験研究に基づいている。人間に 対するリスクを問題にする以上，その推定值は人間のデ 一夕のみから求められることが理想ではあるが, 疫学調 查の対象は実際に発生した事象に限られるため, リスク を正確に数量化するにあたって, 条件の不確実性や個体 数の不足など多くの問題を伴う。一般に, リスク評価で は, これらの疫学の限界を補う手段として動物実験のデ ータが用いられている。したがって, 実験で用いられる 動物は生物の一種としての人間（ヒト）のモデルとして 用いられていることになる。しかしながら，七トとそれ 以外の動物にはいうまでもなく生物種差が存在し, 実験 動物の反応が七トに扔ける現象を正しく反映していると は限らない。これらの問題は, あらゆる環境要因のリス ク評価において共通する問題であり, ラドンについても 例外ではない。

ラドンの健康影響については, これまでに多くの疫学 研究があるが, 必ずしも一定の結果が得られているとは 限らない。またこれを補うべき動物実験も世界的に見れ ば一部の国々（フランス，イギリス，アメリカなど）で 行われているのみで, 数量的なりスク評価という点では 現在のところこれらの動物実験データが十分に活かされ ているとは言えない。そこで, 本報告では, 動物実験の

*1 国立公衆衛生院放射線衛生学部；東京都港区白金台 4-6-1 ( $\mathbf{T}$ 108-8638)

National Institute of Public Health;4-6-1, Shirokanedai, Minato-ku, Tokyo 108-8638, Japan.
ヒトへの外挿について, まず一般的な問題を述べ, 次に ラドンのリスク評価における現状や問題点, および若干 の私見などを述べる。

\section{2 動物実験のヒトへの外挿における一般的な問題}

まず，問題を一般化するために，ある環境要因への曝 露とそれに対する生物の反応を以下のような形で示す。 すなわち, 生物個体の反応を $R$, 生物種差に関する因子 を $\alpha$, 個体の感受性に関する因子を $\beta$, 環境に関する因 子を $\gamma$, 個体差に関する因子を $\delta$, 実験誤差を $\varepsilon$ と扔け ば， $R$ に対するこれらの因子の寄与は, 何らかの関数 $f$ を用いて一般的に次のように表すことができる。

$R=f(\alpha, \beta, \gamma, \delta, \varepsilon)$

ただし, 反応が集団における割合（率）で観測される場 合, 個体差は観測不可能であり, また個々の個体につい て反応が観察される場合でも, 個体差のうち, 何らかの 実験的方法で観測可能な部分は個体の感受性に含まれ, そうでない部分は実験誤差に含まれると考えられる。し たがって, 上式を, 別の関数 $g$ を用いて, より一般的な 形で表せば

$$
R=g(\alpha, \beta, \gamma)+\varepsilon
$$

となる。なお, 関数 $g$ については, 各因子の寄与が相加 的に表される場合や, 相乗的あるいはもつと複雑な形で 表される場合もある。また, 各因子が変数の場合もあれ ばパラメータの場合もある。

動物実験のヒトへの外挿の問題は, ある動物種を用い た実験結果を別の動物種（通常はヒト）に外挿できるか どうかという問題であり, 換言すれば，ある特定の反応 について，まず $\alpha$ (種差) が無視できるか否か, もしそ れが無視できないとすれば， $R$ (反応) と, $\beta$ (個体の感 
第 1 表 ラドンに関する動物実験と疫学研究で得られている主な情報の種類

\begin{tabular}{|c|c|c|}
\hline 生物種 $(\alpha)$ & 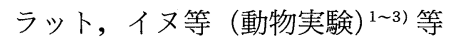 & ヒト (疫学調査 $)^{4 \sim 6)}$ 等 \\
\hline 個体の感受性（ $\beta$ ) & 性別, 曝露時年 (月) 齢等 & 性別，年齢等 \\
\hline \multirow{6}{*}{ 環境因子 $(\gamma)$} & 線量（25～10000 WLM） & 線量（100～1000 WLM） \\
\hline & 濃度（2～1500 WLM） & 濃度（～10 WL） \\
\hline & 曝露時間 & 喫煙量 \\
\hline & 曝露後経過時間 & 生活習慣 \\
\hline & 他因子の同時曝露 & 居住地域 \\
\hline & 等 & 等 \\
\hline \multirow{5}{*}{ 反応 $(R)$} & 肺ガン発生率 & 肺ガン発生率 \\
\hline & 肺ガン死亡率 & 肺ガン死亡率 \\
\hline & 曝露後生存日数 & 肺ガンの組織学的分類 \\
\hline & 腫瘍の組織学的所見 & 等 \\
\hline & 等 & \\
\hline
\end{tabular}

受性）や $\gamma$ （環境要因）との関係に $\alpha$ がどのように関わ っているかという問題であると考えられる。一般には, $\alpha$ が, $R$ と $\gamma$ との関係に直接影響を与えているというよ $\eta$, 生物種 $\alpha$ によって個体の感受性 $\beta$ に違いがあり, そ れが反応 $R$ と環境要因 $\gamma$ との関係に影響を与えている と思われる。例えば, 特定の動物種において, $R$ と $\gamma$ と の間にある線量一反応関係が観察されたとする。この両 者の関係には当然 $\beta$ が影響を与えている。しかし，この 反応に関して生物種差により感受性に違いがないという ことがわかっていれば，前述の関数 $g$ において $\alpha$ を無 視することができ，動物実験を七トに外挿することが可 能になるといえる。

しかし，現実問題はもう少し複雑である。まず，環境 要因 $\gamma$ は, ある要因の曝露量やそれとは別の環境要因に 関する変数，パラメー夕またはそれらの関数などで表さ れるが, 懪露量そのものが疫学的研究と実験的研究では 同一の指標で観測できない場合もある。このような場合 は， $\alpha$ による差異を議論することに意味がなくなってし まう。もう 1 つの問題は, 個体の感受性 $\beta$ に影響を与え る要素がきわめて多く存在することである。例えば, 間 接的な要素として個体の年齢, 性別, 体重, 曝露時の年 齢などがあり, 直接的な要素として, 対象物質に関する 生体における吸収, 代謝, 組織・臟器中の分布などが考 えられる。しかし, 通常は, 生物種による感受性の違い についてすべてを定量的に把握し,さらに関数の形で示 すことは容易でない。したがって, より現実的なアプロ ーチとしては, まず, 特定の反応に関してどのような感 受性の要因が重要であるかを探し出し，その要因につい
$て \alpha$ によ $\beta$ の定量的差異を知り, 次に $R$ と $\gamma$ の関係 に影響を及ぼすこの主要な $\beta$ に関して, 定量的差異を用 いて補正を行うなどの方法が考えられる。例えば，ある 反応に関して，個体の感受性が体重でおよそ決まるとす れば，生物種間で体重による補正を行うことにより動物 実験を別の生物種へ外挿することができる。

\section{3 ラドンのリスク評価における動物実験のヒトへ} の外挿の現状

1）動物実験と疫学研究における各因子

上記の各因子 $(\alpha, \beta, \gamma, R)$ について，これまでの ラドン影響に関する動物実験と疫学調査においてどのよ うな種類の情報が得られているかを第 1 表に整理した。 この表から, 両研究に共通する多くの指標に関してデー 夕が得られていることがわかる。一方, 感受性に関して 得られているデー夕は年齢や性別など間接的な指標であ り, 直接的な指標やそれらの定量的な差異については, 現時点では十分な知見は得られていない。さらに，動物 実験から得られているデー夕として, とくに線量率効果, 複合効果などは, 疫学調查では得難いデータであり, き わめて重要な情報である。

2) モデル動物

ラドン影響に関する多くの動物実験では，ヒトのモデ ル動物としてラットが用いられている。その理由は, 年 齢に依存する自然発生の発ガンのパターンがヒトと類似 していること，とくに肺ガンに関しては好発時期や悪化 の速度が似ていること, 肺ガンの組織像がヒトのそれと 類似していること，個体数をそろえやすいこと，寿命が 数年であること，大きさが適当であること，などである。 
第 2 表 ラット,イヌ, ヒトにおけるラドン曝露によ る肺ガンのリスク*

\begin{tabular}{ccc}
\hline & $\begin{array}{c}\text { 総曝露量 } \\
(\text { WLM })\end{array}$ & $\begin{array}{l}\text { リスク係数 } \\
\left(\mathrm{WLM}^{-1}\right)\end{array}$ \\
\hline ラット & $25 \sim 10000$ & $0.1 \sim 9 \times 10^{-4}$ \\
イ & $13000 \sim 15000$ & $0.3 \sim 2 \times 10^{-5}$ \\
ヒト & $100 \sim 2000$ & $1 \sim 4 \times 10^{-4}$ \\
\hline
\end{tabular}

*文献 1） p. 42 より抜粋

これらの理由のうち, 実験の実行面における効率性や経 済性も重要な要素であることは否定できない。一方，ラ ドンに関する動物実験および疫学調查から得られた各動 物種の肺ガンのリスク係数 (1 WLM あたり生涯リスク) を比較した場合 (第 2 表参照)，ラットとヒトでは近い值 を示すことが報告されている。また，この両種に比べて イヌのラドンに対する感受性が低いことも示唆されてい る。

\section{3) 問題点}

一般的な問題の項で述べたことがラドンのリスク評価 の場合にもあてはまる。すなわち，動物実験をヒトへ外 挿するためには，まず，環境要因に関する各指標が動物 実験および疫学の両方に共通して用いられることが必要 である。しかし，ラドン娘核種の気道への吸着メカニズ ムや, WLM 単位の線量としての精度, WLM から吸収 線量 $(\mathrm{Gy})$ への変換係数など, 解明すべき点は多い。と くに，呼吸気道における線量は，環境要因であると同時 に生物側の要因にも関係するため，前述した関係式に単 純には当てはまらない面を持っている。また，個体の感 受性のうち, ラドンのリスクにとってどのような指標が 重要であるか，または決定的な要素が何であるかなどに ついては，ほとんど明らかにされていない。この問題は ラドン吸入による発ガンのメカニズムとも関係し，これ らのメカニズムの解明が動物実験のヒトへの外挿におい て重要な根拠になるであろう。さらに，疫学と同様に， 動物実験においても低線量の影響を調べるためには多く の個体数を必要とする。したがって，きわめて低い線量 域で大量の実験動物を用いることが不可能であると考え られる場合には，動物実験からヒトへの外挿だけでな く, 高線量加ら低線量への外挿という別の問題も加わる ことになる。

\section{4 ま め}

動物実験をヒトに外挿できるかどうかという問題は, ある生物種における環境要因と生体反応との関係を, 異 なる生物種に適用することが可能かどうか，あるいはそ
のような外插を行うことができるという科学的根拠が存 在するのか，という問題と同じである。この問題に対す る一般的な解答の 1 つは，既に述べたように，現実的に は困難を伴うとしても，種差による感受性の差異を定量 的に把握することができれば，それが動物実験のヒトへ の外挿を可能にする根拠となりうるということである。

しかし，実際のリスク評価の場面においては，概念的 な根拠ではなくもう少し現実的な根拠あるいはアプロー チが必要である。ラドンのリスク評価の場合には，実験 動物としてはラットが最も多用されており，その根拠は 既述のと抢りである。ただし，その根拠はラドンに対す る反応パターンやガンの組織像がヒトに似ているとい う，いわば現象面での類似性に基づいている。もちろん このような現象面での類似性は，ラドンに対する感受性 がヒトとラットとで似ていることを示唆してはいるが， 動物実験からヒトへの外挿はあくまでも予測あるいは近 似であり，ヒトにおける反応を厳密に再現するものでは ない。したがって，動物実験をヒトへ外挿する際に最も 重要な点は，定量的な予測の精度や感度をできるだけ高 めるように実験や解析方法を改善していくことである。 そのためには，ヒトとラットにつき，ラドンに対する個 体の感受性についての類似性（あるいは差異）を明らか にしていくべきであろう。

ラットを用いた動物実験がヒトのラドンに対する反応 をどの程度正確に近似しているか，その精度を測る決定 的な手段は今のところない。また，実験動物の選択につ いてはラット以外の動物を用いる明確な理由がない以 上，現時点ではラットが最も適切であると考えられてい る。リスク評価におけるヒトのモデルとしての動物実験 には，な扢改善の余地が多いものの，ラドンについて言 えば，線量率効果や複合効果などが動物実験により明ら かにされてきており7)，ヒトの反応について多くの示唆 を与えていることは言うまでもない。

\section{参 考 文 献}

1) COGEMA ; Radon. Trente ans de recherches sur ses effets biologique à doses élevées, COGEMA (1994).

2) F.T. Cross, R.F. Palmer, R.E. Filipy, G.E. Dagle and B.O. STUART ; Carcinogenic effects of radon daughters, uranium ore dust and cigarette smoke in beagle dogs, Health Phys., 42, 33-52 (1982).

3) F.T. Cross, R.L. Buschbom, G.E. Dagle, K.M. Gideon, R.A. Gies and E.S. GilberT ; Inhalation hazards to uranium miners, In Pacific Northwest 
Laboratory Annual Report for 1990 to the DOE

Office of Energy Research, part I: Biomedical Sciences, Pacific Northwest Laboratory, Richland, Washington, pp. 45-50 (1991).

4) G.R. Howe, R.C. Nair, H.B. Newcombe, A.B. Miller and J.D. ABBAT ; Lung cancer mortality (1950-80) in relation to radon daughter exposure in a cohort of workers at the Eldorado Beaverlodge uranium mine, J. Natl. Cancer Inst., 77, 357-362 (1986).

5) J.M. Samet, R. Pathak, M.V. Morgan, M.C.
Marbury, C.R. Key and A.A. Valdivia ; Radon progency exposure and lung cancer risk in New Mexico U miners : a case-control study, Health Phys., 56, 415-421 (1989).

6) UNSCEAR ; Source and Effects of Ionizing Radiation, New York, United Nations (1988).

7) G. Monchaux, J.P. Morlier, M. Morin, J. Chameaud, L. Lafuma and R. Masse ; Carcinogenic and cocarcinogenic effects of radon and radon daughters in rats, Environ. Health Perspectives, 102(1), 64-73 (1994). 